\title{
Correction to: Ivosidenib: First Global Approval
}

\author{
Sohita Dhillon ${ }^{1}$
}

Published online: 4 January 2019

(c) Springer Nature 2019

\section{Correction to: Drugs (2018) 78(14):1509-1516 https://doi.org/10.1007/s40265-018-0978-3}

The article Ivosidenib: First Global Approval, written by SÛohita Dhillon, was originally published Online First without open access. After publication in volume 78, issue 14, pages 1509-1516 Agios Pharmaceuticals requested that the article be Open Choice to make the article an open access publication. Post-publication open access was funded by Agios Pharmaceuticals. The article is forthwith distributed under the terms of the Creative Commons Attribution-NonCommercial 4.0 International License (http://creativeco mmons.org/licenses/by-nc/4.0/), which permits any noncommercial use, duplication, adaptation, distribution and reproduction in any medium or format, as long as you give appropriate credit to the original author(s) and the source, provide a link to the Creative Commons license and indicate if changes were made.

The original article has been corrected.

Open Access This article is distributed under the terms of the Creative Commons Attribution-NonCommercial 4.0 International License (http://creativecommons.org/licenses/by-nc/4.0/), which permits any noncommercial use, distribution, and reproduction in any medium, provided you give appropriate credit to the original author(s) and the source, provide a link to the Creative Commons license, and indicate if changes were made.
The original article can be found online at https://doi.org/10.1007/ s40265-018-0978-3.

Sohita Dhillon

dru@adis.com

1 Springer, Private Bag 65901, Mairangi Bay, Auckland 0754, New Zealand 